\title{
Suspended commodification: assetization and the politics of silobolsa in Argentine soybean agriculture
}

\section{Pierre Delvenne}

To cite this article: Pierre Delvenne (2020): Suspended commodification: assetization and the politics of silobolsa in Argentine soybean agriculture, Journal of Cultural Economy, DOI: $10.1080 / 17530350.2020 .1761429$

To link to this article: https://doi.org/10.1080/17530350.2020.1761429

\section{曲 Published online: 20 May 2020.}

Submit your article to this journal

Q View related articles $\sqsubset$

View Crossmark data $\asymp$ 


\title{
Suspended commodification: assetization and the politics of silobolsa in Argentine soybean agriculture
}

\author{
Pierre Delvenne \\ Department of Political Science, Spiral Research Centre, University of Liège, Liège, Belgium
}

\begin{abstract}
Based on a rich empirical description of processes of soybean commodification in Argentina, the article puts a neglected technological device at the centre of the analysis: 'silobolsas,' allowing farmers to conserve their harvest in plastic bags with specific properties. Storing soybeans in 'silobolsas' opens up the possibility of (precariously) preserving their value or holding up commercial exchanges waiting for better conditions. The politics of silobolsa exhibits that commodities and assets nestle beside each other, but also incorporate each other's characteristics, change into each other, or confuse different actors about their commodity-versus-asset identities. Three particular contributions to the existing literature on commodities can be singled out: first, immobility can be as illuminating as movement to make sense of the sociotechnical context of commodities. Second, the lack of exchange is a form of politics that participates in the social practices configuring the value of commodities. Third, complex temporal processes of commodification and assetization can significantly mark the social life of the same 'thing.' These findings speak to the most recent mutations of contemporary capitalism that is itself increasingly characterized by the (re)configuration of a range of things as assets or capitalized property.
\end{abstract}

\section{ARTICLE HISTORY}

Received 1 August 2019

Accepted 6 April 2020

\section{KEYWORDS}

Commodity; asset;

commodification; Argentina;

soybean; silobolsa

\section{Introduction}

Argentine agriculture has undergone significant transformations over the last three decades, elevating the country to a leading position on agricultural commodity markets (Trigo et al. 2009). The annual production of grains, of which the most important varieties are soybeans, corn, and wheat, went from 50 million tons in the 1996/97 season to 140 million tons in 2018/19. The benefits generated by this export-oriented agricultural model are enormous. According to this agricultural journalist from Clarín, the largest tabloid newspaper in Argentina, the expected revenues from the most recent harvest promise to be very satisfactory:

It is estimated that this year's harvest of 140 million tons, which will be a record for Argentina, will generate foreign exchange for US \$28,000 million, US \$ 7,000 million more than what the harvest generated last year. Soybeans, once again, are expected to lead the production of crops with 56 million tons, but cereals should not be left behind: 48 million tons of corn are expected and the wheat that was harvested reached 19 million tons. (Clarín Rural 2019)

Argentina is a country with a long-standing agricultural profile that is often portrayed as 'the granary of world' (Delvenne 2017). The country has become the world's third producer and exporter of genetically modified crops. In fact, its current position on agricultural commodity markets owes a 
lot to the massive adoption of the glyphosate-tolerant soybeans, from the second half of the 1990s, which has been the most rapid adoption of any seed variety in the country, including those introduced in the Green Revolution (Penna and Lema 2003). This economic success ${ }^{1}$ is partly due to the international situation of the early 2000s, when there was a sustained demand for soybean products, notably from emerging markets of China and India, coupled with a high price of commodities on global markets.

Yet, to a large extent, the huge success of soybeans as the country's leading commodity is also due to the contingent entanglement of herbicide-tolerant soybeans with two 'national' breakthroughs in farming practices: no-till farming techniques and a grain storage technological device called 'silobolsa' (or silo bag). While the former has already attracted a lot of attention in science and technology studies (STS) and rural sociology (Goulet and Hernandez 2011, Goulet 2013, Hernandez 2013), there is a lack of social science studies addressing the latter, in spite of its central role in leveraging agricultural change in Argentina. This article wants to address that shortage. If no-till farming practices are key to the production of crops, the diffusion of silobolsa was instrumental to manage the expanding flow of commodities and to facilitate the coordination of actors during the commercialization phase of crops.

By paying central attention to the politics of packaging agricultural commodities with a plastic bag, I explore how political and the ontological processes interact inasmuch as silobolsa becomes an ordinary sociotechnical device. This attempt connects with recent debates on plastic packaging and its ontological and political effects on food/feed in the market (cf. Hawkins 2018). In this case, however, rather than a 'skin of commerce' (Hawkins 2018), the plastic skin that envelops soybeans temporarily isolates them from commodity market transactions. Yet, similar to Hawkins' fascinating history of plastic food packaging in Australia, I show that the constitution of silobolsa as a mundane market device (Neyland et al. 2018) prompted tremendous political and ontological effects, suspending the commodity status of soybeans. Inspired by Cochoy's work (2007) on food packaging, I stress how the package transforms the qualification of the product itself and is repeatedly intertwined with public issues. Yet, in the case of silobolsa, the package does not alter the relationship between a grocer and a consumer, as is often stressed in sociological analyses pointing at the agency of food packages (Murcott 2019). When it is storing raw commodities like soybeans, the package is not used to provide any additional, or otherwise invisible, information on the product it contains, but rather to allow for an extended conservation time and a greater empowerment of farmers. Unlike foodstuffs, soybeans as commodities are never sold with packaging. Instead, the market transaction is only possible when soybeans are removed from their plastic container and are circulating again. ${ }^{2}$ At the difference with refrigerators, freezers and many other devices that allowed for storing perishable things and extending their conservation time, silobolsas stand out in that they made storage cheaper and more accessible for small producers.

By bringing such a neglected technological device as silobolsa to bear on the performance of commodification, I want to investigate the life history of soybeans by following their journey as they are produced and commercialized in Argentina. In his seminal paper on the social life of commodities, Appadurai forcefully argued that 'to anthropologically observe the truth about commodities, one has to follow their circulation, their multiple forms, their trajectories' (Appadurai 1986, p. 5). I adopt his open-ended definition of a commodity being 'anything intended for exchange' and, likewise, I approach commodities from the perspective of their circulation because 'it's a methodological rather than a theoretical point, as it's the things-in-motion that illuminate their human and social context' (Appadurai 1986, p. 16).

More recently, Tsing (2013) stressed that commodities are defined by the alienation that constitutes them, that is their separation from their producer and fabrication context. Her remarkable contribution shows that even when things are exchanged, their commodity status should not be taken for granted. Indeed, I hypothesize that the commodity status of soybeans may be questioned when it is stored in silobolsas, as it remains attached to its producer, kept in the fields where it was grown. I postulate that commodification is temporarily interrupted and, for a limited period of time, that 
soybeans become suspended commodities. Even though soybeans remain produced for exchange, their established 'path' (Appadurai 1986) is diverted by the use of silobolsa. When farmers decide not to sell their harvest and to keep their grains stored in silobolsas instead, the value of crops is precariously preserved, and alienation (the separation of soybeans from farmers and fields) is delayed for a few months, up to a couple of years.

Of course, storing grains in silobolsas does not eventually prevent the commodification and financialization of soybeans. Yet, I argue that storing them in plastic bags constitutes a step aside from the usual commodification route: in the temporary absence of alienation and exchange, commodities become assets.

In its 2015 IFRS (International Financial Reporting Standard) report for small and mediumsized entities, the International Accounting Standard Board defines an asset as 'a resource controlled by an entity as a result of past events and from which future economic benefits are expected to flow to that entity' (p. 15). As for Birch and Tyfield (2013, p. 302), they define an asset as 'a tangible or intangible resource that can be used to produce value and, at the same time, has value as property.' Since there are multiple classes of assets, it should be made clear that the kind of asset I am talking about here is not a financial asset, such as a market derivative (i.e. futures or options contracts). Rather, in a silobolsa, soybeans are transformed into near-money: highly liquid assets, which are not cash, but a virtual currency that can easily be converted into cash. This near-money status of soybeans is related with a wider imagination of money in Argentina, a country that has fuelled a fairly peculiar relationship to liquid cash after repeated inflation crises and runs on banks. Nicholas d'Avellas's work (i.e. d'Avella 2014) on ecologies of investment nicely stress the contrast between money and bricks as forms of investment in contemporary Argentina. In this article, I bring another form of 'investment practice' to the fore, assetized soybean (i.e. soybean temporarily stored in a silobolsa), compared with other practices such as investments in bricks as a way to secure monetizable assets. Like bricks, assetized soybean is considered a safe investment that is not centrally about profit but about stability. Yet, unlike bricks, soybean has a greater circulatory power as it can be changed into cash at a much faster rate. Although this is a limited phenomenon compared to the real estate market, storing grains in silobolsas emerges as a form of compromise that makes it possible for farmers to choose both the (relative) stability of value and the circulation capacity.

As I will show, for economic and political reasons, in a macro-economy as unstable and inflationary as Argentina, the subtlety of farmers is to delay the conversion of grains into pesos that will soon be devaluated.

\section{Presentation of the case study}

Introduced in 1994 by technicians from the National Institute of Agricultural Techniques (INTA) from Germany, where it was used to store wet grains as food for livestock, the silobolsa technology was adapted in Argentina to store dry grains in plastic bags, at low cost and with optimal quality conditions for up to two years. The bags are made of low density polyethylene approximately 250 microns thick and manufactured by the extrusion method.

A silobolsa consists of three layers of which the outside is white, has special additives, such as titanium dioxide, and serves to reflect much of the radiation. The intermediate layer does not have special characteristics, while the interior layer is black to avoid ultraviolet rays. These plastic cylinders often measure approximately 75 metres long with a height of 2.70 metres and have a storage capacity of up to 200 tons. Each one, depending on its size and characteristics, costs between US $\$ 300$ and US $\$ 500$. As there is a significant supply of machinery and related services carried out by rural contractors, this technology has no major barriers to its use. According to inquiries made to agents participating in the sector, the cheap services of both bagging and extraction have an estimated cost of between 70 and 80 pesos per ton (La Capital 2018). 
The silobolsa technology was developed as an alternative to fixed silos. As a former Director of INTA explained to us, that affordable storage system was indispensable to the consolidation of Argentina as a leading agricultural nation:

If there were no silobolsas, Argentina could not produce what it produces because it would not have roads and ports to handle production. (former INTA Director)

Thus, the wide adoption of silobolsa by Argentine farmers also echoes the lack of investment in infrastructures (fixed silos, road transport and port infrastructures). In fact, this mobile storage facility allowed agricultural producers to keep up with the rapid 'soy-ization of Argentina' (Delvenne et al. 2013). Above all, silobolsa was a suitable addition to an agricultural system that mostly operates through land leases and third-party contracting (Anlló et al. 2013, Leguizamon 2016), as this journalist from the news website Infobae explains:

As with many technological advances, the silobolsa was also born from a need; in this case, the need for storage versus the lack of financing to execute investments in own storage capacity, combined with the significant growth of grain production and the fact that much of the production is done in leased fields, which makes the installation of a fixed silo unviable. (Infobae 2018)

Silobolsa brings significant logistical and commercialization benefits to the producer, since it allows him to manage the timescale of the sale of the grains to achieve better prices. Today this technology has given impetus to an important national industry that includes machinery and services for bagging, extracting and transporting grains, which today are exported to more than 50 countries (La Capital 2018).

Retaining grains has been a central strategy in agricultural commodity markets for decades, both on state (trade boards) and on company levels. For instance, Cronon (1991) famously described how, in nineteenth century Chicago, farmers driven by new technological possibilities progressively removed grains from its sacks to favour its circulation and trade through grain elevators. Because it was speculating and gambling on the crops, the Chicago Board of Trade, in spite on its role in improving the efficiency of trade and transport of grains alike, was accused of standing between the farmers and the ultimate market to which its grain must go.

In my story, however, it's not the Rosario Board of Trade that stands in the way of commodity circulation and trading, nor is it the Board that innovated to improve grains' trade and transport. Instead, I account how a new technology, silobolsa, was developed by a public institute for agricultural techniques (INTA) to protect and store grains, then subsequently taken over by farmers who, to some extent, diverted this technology to precariously assert themselves as new intermediaries in speculation activities. Thus, the obstructions to market transactions are prompted by farmers themselves, who find themselves vulnerable when grains are piled at the port and the grain collector (acopio) sets up its market price once for all.

While historical technological innovations like grain elevators turned grains into commodities and 'distanced them from the physical universal of fields and crops and rural nature' (Cronon 1991, p. 146), silobolsa delays such a distancing and interrupts the commodity phase of soybeans. This does not mean, however, that silobolsa reconnects crops with rural nature, nor that it prevents the market abstractions to intersect with the farming business. In her study on soybean agribusiness in Argentina, Leguizamon (2016, p. 3) argues that

\footnotetext{
the push for technological innovation by large-scale agribusinesses engaged in soybean production, in articulation with financial sector involvement, are both an example of and are instrumental in the process of 'distancing' (increasing the distance from farm to plate) and 'abstracting'. (turning physical commodities into market derivatives)
}

Her contribution to the agro-food literature is to show 'how the processes of distancing and abstracting happen from the ground up, starting with the farmer in the field' (Leguizamon 2016, p. 7). With my emphasis on the politics of silobolsa, I point at other micro processes driven by farmers in the 
field, which should not remain unnoticed because they are directly connected to, and mutually shaped by, macro political-economic processes.

An innovative co-productionist approach (Jasanoff 2004, Joly 2015) is followed, initiating an interdisciplinary conversation between STS and political economy. By stressing the 'politicization' of silobolsa, I emphasize that the plastic bag acquires political capabilities in its own right, in the sense of being became capable of effecting changes and actions in certain ways. Yet I also stress how the plastic bag can be taken as a privileged site to observe the articulation between the economic and the political and their embedding in broader sets of social relations, as it increasingly becomes the object of wider political deliberations and contestations. I indeed show that the breakthrough in national farming practices constituted by silobolsa contributes to shifting asymmetric power relations at the micro level of farmers and the macro level of capitalist dynamics. Therefore, silobolsas are not just embedded in multifaceted struggles and shaped by them, but are a site for such struggles and in this way, contribute to changes in the reconfiguration of power.

To inform my analysis, I rely on STS and political economy of science and technology literature and secondary data analysis (press articles, regulatory and legal documents) as well as on extensive fieldwork that was conducted in Argentina from 2010 to 2016. Fieldwork was based on 62 semistructured interviews (8 in 2010, 31 in 2011 and 6 in 2015, 17 in 2016) in Buenos Aires and Rosario, to actors involved in the soybean complex or that have had a say in the public discussion around it (including members of academia, public administration, seed and agrochemical companies, agricultural production, regulation, distribution sectors, financial investors, managers of sowing pools, and related civil society organizations). Some of the key informants were interviewed up to three times and the interviews were systematically analyzed, categorized and tagged with the qualitative software Mosaiqs. To preserve the anonymity of interviewees, this version of the article presents the excerpts without linking them to their authors.

\section{The political-economic context of commodities ${ }^{3}$}

To understand the roots of the agricultural commodity system in Argentina ${ }^{4}$, one has to go back in history, at least to President Carlos Menem's administrations (1989-1995 and 1995-1999) when the agricultural sector was at the forefront of a neoliberalization process. The national government approved the commercialization of herbicide-tolerant soybean in 1996 and the biotechnology regulatory regime was transformed on the basis of market principles benefiting large corporations (Otero 2012, Anlló et al. 2013, Delvenne et al. 2013). Menem's government reduced farm subsidies and trade protections and increased interest rates on agricultural loans.

After 1997, the economy experienced a sharp decline and unemployment soared (Caceres, 2015, p. 120), eventually leading to the $2001 \mathrm{crash}$, when the neoliberal model of a decade of Menemismo collapsed and forced Argentina to declare a partial default on its national debt (Teubal and Teubal 2011). At that time, half of Argentines were living in poverty, amongst the highest rates of inequality in history, with immense despair in a context of institutional, political, and economic crisis (Carranza 2005, Leguizamon 2016, p. 155). Five different presidents succeeded each other in less than 10 days during the 2001 crisis. The fifth of them was Eduardo Duhalde, who decided to abandon convertibility with the USD, to devalue the peso, and to call for a general election (Caceres 2015, p. 121). The Peronist political party then came back to power: Néstor Kirchner was elected president (2003-2007), to be followed by his wife Cristina Fernández de Kirchner (2007-2011 and 20112015), what political analysts called the 'Kirchnerist' period. Kirchnerism was however not a monolithic block. Argentinean political economist Mathias Kulfas (2016) considers that the country has known three types of kirchnerism.

The first kirchnerism started with Néstor Kirchner's presidency, which was a historical moment for soybean export and profitability. During this time, there was a sustained international demand for soybean products (notably from emerging markets of China and India) coupled with a high price of commodities on global markets. Richardson (2009) coined the term 'export-oriented 
populism' to argue that under Néstor Kirchner's government, changes in agricultural production (soybean replacing wheat and meat as the country's leading export commodity) and productivity (which dramatically increased as an effect of the adoption of the soybean technological package ${ }^{5}$ ) created the conditions of a new variant of populism, temporarily eliminating important sources of political and economic instability that had plagued previous incarnations of Argentine populism.

Because soybean is not consumed by the working class, Kirchner could both promote and tax their export, generating fiscal revenue for populist programs while not harming the effective purchasing power of urban workers or provoking a balance-of-payments crisis. (Richardon 2009, p. 228)

Export-oriented populism even expanded under the second kirchnerism, coinciding with Cristina Fernández de Kirchner's first presidency (2007-2015), as she decided to increase the export taxes from 30 percent to 35 percent.

Increasing foreign income from agricultural exports and higher fiscal revenue explain how it was possible for the Kirchners to return to a model of state intervention, investing in infrastructure and social spending, without enacting major structural reform, thus keeping intact the agro-export model devised in the neoliberal 1990s.

(Leguizamón 2014, p.156)

The Kirchners thus conserved and reinforced the transgenic soy model they inherited, as 'both neoliberal and post-neoliberal governments have relied on state policy to intensify Argentina's comparative advantage.' (Leguizamon 2014, p. 158).

However, this strategy was severely challenged by a series of crises. The global financial crisis of 2008-2009 eventually eroded Argentinean growth rates; a major drought in 2008 curtailed soy production; the slow erosion of international prices of agricultural commodities reduced returns on soy; and most importantly, in 2008 the countryside rose up against Cristina Kirchner's government, after she announced her intention to increase the export tax on soy to 50 percent. Kirchner attempted to do this through executive measure ('Resolucion 125') to avoid having it voted on by Parliament (see Hora 2010, Fraga and Baistrocchi 2011). That attempt failed and sparked a conflict that paralyzed the country for several months: roads and bridges were blocked and there were massive street demonstrations and public events against Cristina Kirchner.

That conflict, and the related socio-economic and political struggles that occurred in its aftermath, seriously plagued the third kirchnerism (corresponding to the second mandate of Cristina Kirchner, 2011-2015), which experienced a significant economic downturn: almost zero growth, a sharp decrease in private investment, and a sustained drop in commodity prices. The combination of these factors from 2008 were a real turning point in the politicization of silobolsas. In the past decade, farmers started to see slimmer profit margins: while in 2012 soybeans were worth $650 \mathrm{USD} /$ ton, today its quotation is around 330USD/ton. This prospect has rekindled fears of falling prices as in 2008, at its historic bottom rate, when soybeans were worth $287 \mathrm{USD} /$ ton. Consequently, in the past few years many farmers have significantly increased their use of silobolsa. In turn, as will be developed in the next section, resorting to silobolsa started to be portrayed as a political act of speculation on commodity prices, and even a betrayal of the homeland economic sovereignty. Nevertheless, it is not speculation on grains yet to come: it is speculation on the future market value of grains that already exist and whose biophysical properties may be temporarily neglected when stored in a plastic bag.

\section{Turning soybean into more than just commodities: the politics of silobolsa}

In 2002, according to national experts, around 2 million tons of grains (corn, wheat, soybeans, and sunflower) were stored in silobolsas. Since then, the use of that storage technique has dramatically increased:

in recent years, the technique has been improved and the silobolsa has gained rapid adoption among Argentine farmers, to the point that in 2010 more than 40 million tons were stored in silobolsas - that represents more than $40 \%$ of total production. (Buzzato et al. 2011, p. 865) 
Numbers continued to skyrocket in the last decade, as most recent estimates project that, in 2019, around 80 million tons of crops could end up in this form of storage, so the market would demand around 400 thousand units of silobolsas (La Voz 2019). How can it be explained that the use of this storage technique has multiplied by 40 in just over 15 years?

To start with, there are various advantages to the use of the silobolsa. First, it allows farmers to maximize the use of harvesting equipment. Second, in case of adverse weather conditions, the harvest can be stored in the field waiting for better conditions to transport it. Third, it allows savings in freight and permits a better organization of the post-harvest period. Fourth, and foremost, it gives farmers the possibility to extend the phase of commercialization, and wait for better prices for their harvest. As was stressed above, the use of the silobolsa does not present major complexities and the implementation of this storage system is very affordable. The high adoption rate of this technological device certainly has to do with the higher yields obtained through better weed control and greater productivity (notably due to the adoption of the technological package). But there is another advantage that must be mentioned: silobolsa decreases the relative vulnerability of farmers in the post-harvest period. Indeed, as economic agents, selling their grains and submitting themselves to the conditions of the commodity market is a moment of heightened vulnerability:

For me, the silobolsa is fundamental because it removes the vulnerability in the commercialization stage that is a time of exposure for farmers who find themselves in a situation of relative weakness. (INTA official)

This vulnerability is even more important in time of economic hardship. In that case, farmers rely on silobolsa to protect their harvest not only from adverse weather conditions, but also and especially from unstable political and macroeconomic conditions. In a silobolsa, their soybeans are turned into a store of value and become the object of speculation. Farmers' decisions on whether they shall open their silobolsas and sell their grains are based on fictional, rather than rational, expectations that establish, which economic activities are pursued or abstained from. According to Beckert (2013) 'fictional expectations refer to present imaginaries of future situations that provide orientation in decision-making despite the incalculability of outcomes [...] Rather than forecasts, these expectations must inhabit the mind as imagined future states of the world' (Beckert 2013, p. 325). By ever expecting the depreciation of the national currency against the dollar, or by speculating on the rise of the price of the ton of crops, farmers are 'playing to wait' (Perfil 2019) and betting so they could achieve better prices.

The adoption by farmers of the assumption that the value of their national currency will have deteriorated at the point in time when they want to use it for the purchase of goods acts as a very stable fictional expectation of monetary variance (Mirowski 1991). Prefiguring the next political sequence of events with the upcoming Presidential elections, this columnist aptly captures the sense of déjà-vu characterizing this enduring expectation and its possible consequences:

Governments change, but history, with some variations, seems to repeat itself: in the electoral pre-election, the Central Bank's firepower and the level of reserves is once again at the centre of the debate. In addition, dollarization fever by savers is once again an agenda item and the role that the countryside may have, contributing the necessary foreign currency, becomes a state matter. (Iprofessional 2019)

\section{The former Executive Director of ROFEX (Rosario Futures Exchanges) ${ }^{6}$ explains that}

[farmers'] strategy [...] is to use soybean as a store of value, and instead of selling the beans to obtain liquidity and thus have working capital, they prefer to keep soybean or corn and take debt in dollars to a rate of $4 \%$ per year. (Clarín Economía 2017).

Yet, because of structural inflation and the high volatility of prices on international markets, the same informant acknowledges that such an endeavour is a risky business

Looking forward with today's prices, it seems like a good business. But those who, for example, have been withholding soybean for a year did not do very well. The more or less bottom rate of the dollar, growing less than inflation, generated a major breakdown, since costs continued to rise at a greater rate than the dollar. [... Yet,] 
for one reason or another, the local producers have a hard time selling soybean, they prefer it to the peso, from now on, but also to the dollar, in the jargon [we say] they bet on the rise of the grain. (Clarín Economía 2017)

More recently, an official from the Rosario Board of Trade even compared soybean with a currency: 'the [commodity] producer is used to saving on grain and knows that his best currency is soybean' (Clarín Rural 2019). Thus, even though their capacity to intervene in the fixation of crop prices on the international commodity market is close to zero, farmers use the margins they have on the commercialization side to their own advantages. Obviously, a way to regain leverage and push back their vulnerability vis-à-vis the commodity market is to store part of their harvest in silobolas. When resorting to this technology, a crucial question for every farmer is: how much time should I keep my grains in the bag or, conversely, when should I decide (and how should I know) that it is the right time to sell them off? For calculating agencies of farmers, the time lag is a decisive factor behind the switch from the asset situation to the commodity system again (Callon 1998, Callon et al. 2007). The information underpinning their choices is never sufficient to dissipate the radical uncertainties with regard to the future of exchange rate peso/dollar, the magnitude of inflationary outbreaks combined with the possible rise of interest rates, or the upcoming political events, like the amount of export taxes that will depend on the result of the next Presidential elections, or the unknown consequences on commodity markets of the commercial war between China and the US.

Hence, the farmers' decision is always based on partial and contingent interpretations of how they make sense of their own situation in a highly uncertain political-economic context. The stakes are important for their economic and social condition and, at the same time directly relate to macro outcomes: the quantity of crops available for sale on the market, the amount of domestic and foreign currencies in circulation, and the fiscal revenues generated by export taxes, which the government needs for financing public policies and investments. Retaining soybeans in silobolsas therefore delays both the alienation of farmers and the entry of fresh dollars in the public Treasury:

The silobolsa gives margins to the producer. Do you see how the power differentials are rebalanced? That was not [due to] public intervention, that was a technical change. Not only the exporter, but also the company that has the capacity to grind the grain, which has the physical capacity installed, the ship waiting, the machine grinding in a vacuum, and if there is no truck queue to enter, the guy says: "Let me bring soybeans from Paraguay." It's very funny. Look, to get dollars the previous government [of Cristina Kirchner], a government that called itself 'progressive', had its interests aligned with five multinational companies that have milling capacity. What did they want? Grain! Some to grind and others to get the dollars (Laughter). (Agricultural economist 2)

Many Argentine actors are concerned by farmers' decisions to retain their crops or to let them go. Streams of revenues associated with soybeans' commodification are so important that tensions arise with, and through, the use of silobolsa as a political, and not just agricultural, tool. These tensions may occur between farmers who can afford to wait for better prices and those who cannot, between political factions of both sides of the political spectrum, between the bidding companies and farmers, and of course between the countryside and the government. As this quote from a leading official of the Asociación de Semilleros Argentinos (ASA) illustrates, it is not only artefacts like silobolsa that have politics (Winner 1980), it is also soybeans-as-commodities that become the object of wider political contestations and conflicts:

The silobolsa was almost a containment to the political measures of the previous government [of C. Kirchner] that restricted everything. In the face on uncertainty, the producer had found his own bank that was the silobolsa. It seems to me that the silobolsa should become what it has to be, a store of grain and not a credit facility .../. (ASA official)

In 2015, various vandalism cases were reported in the province of Córdoba, after dozens of silobolsas were destroyed by razors and the soybeans they contained were scattered on the floor. It made the headlines of La Nación, the country's leading conservative newspaper, which published an article entitled 'Silobolsas: the agricultural revolution the Government is obsessed with' (La Nación 2015), in which it was assumed that the wave of attacks against silobolsas had been sparked off by a phrase painted in red on the background of a white wall in the city of Oliva, located 100 
kilometres from Córdoba, that was saying: 'make homeland: cut a silobolsa' (Haga Patria: corte un silobolsa).

\section{Conclusion}

In this paper, I have followed a specific 'thing,' glyphosate-tolerant soybean, as it is commercialized as a commodity in Argentina. Facing uncertain political-economic conditions, Argentine farmers need to address a crucial dilemma with what to do with their agricultural commodities: keeping soybean as a stable 'currency' stored in a silobolsa or exchanging it for soon-to-be-devaluated pesos. Resolving this dilemma is not simply instrumental to their prosperity until next planting season, it also dramatically affects the circulation and status of commodities.

The use of silobolsas to conserve their crops allows farmers to manage and control the dynamics of value in new ways by storing soybeans as assets and gaining control over when they are sold. Because farmers are subjected to the harsh conditions of a commodity economy (competition, race to the bottom, buyer's market, asymmetries in scale and flexibility), many aspects of which are beyond their control, it is a logical consequence that they attempt to temporarily opt out of it. Dealing with time, handling the temporal process of moving things out of circulation, diverting them from flows and making them static, become central matters of concern in the political economy of valuating commodities. Analyzing the 'politics' of silobolsa thus implies going beyond stressing the bags' distinct material capacity to also address the temporality in which they become a potent force in shifting power relations, where power does not radiate downward from a unique focus of domination but constantly induces evolving asymmetric states of power.

The use of silobolsa represents a tactical move by farmers to make sense of and survive in an unstable political-economic landscape they themselves cannot transform - only tweak or slightly modify by changing the form of their good. Kirchnerism assumed that farmers would produce commodities to keep the system going, but a significant number of them temporarily escaped from their designated role through assetization. Although limited in time and depth, the crucial power of intervention of the silobolsa technology may be viewed as a key moment in commodity life: one in which equal emphasis can be put on the agency of more and less powerful actors. Situated struggles related to suspended commodification open up possibilities for analyses of the global politics of commodities, which cannot disregard the 'agentivity' of both the powerful and the powerless.

While it is evident that commodities play a central role in assembling values, politics, economics and materialities, I have shown that processes of commodification and assetization both contribute to, and emerge from, the social life of commodities. Commodification appears as an ongoing, fragile procedure that distributes and aligns subjects and objects in a particular fashion that can be temporarily disrupted, or just interrupted, through the use of technological devices. Building on Appadurai (1986) and Tsing $(2013,2015)$ who question the boundary between commodities and gifts, this paper's original perspective was to extend these analytical perspectives to the (porous) boundary between commodities and assets. By following the path of soybeans in context until its commercialization, I focused on the diversion that occurs when crops are temporarily stored and preserved in a silobolsa. Yet, it is a different diversion from the one Appadurai talks about, because resorting to silobolsa does not mean breaching out to a new path for the commodities it contains; it's rather getting them stuck in their production context for a period of time that can be extended up to a couple of years.

This paper contributes to the existing literature on commodities in at least three important ways: first, methodologically, even if it is crucially instructive to follow things-in-motion, symmetrical attention should be paid to situations or moments when things stop being on the move. In short, immobility can be as illuminating as movement to make sense of the sociotechnical context of commodities. Second, while Appadurai (1986) convincingly argues that politics is what links value and exchange, I additionally showed that the lack of exchange is also a form of politics that participates in the social practices configuring the value of commodities. Third, if things can indeed be retrieved, 
either temporarily or permanently, from the commodity state and placed into some other state (Appadurai 1986, Tsing 2013), it is not only because capitalist commodities gain value through appropriation of non-capitalist social relations, as Tsing (2015) famously demonstrated with the gift-versus-commodity identities of mushrooms. Commodities can also be temporarily converted into another capitalist form - from commodity to asset, to commodity again. This conversion corresponds to the most recent mutations of contemporary capitalism that is itself increasingly characterized by the (re)configuration of a range of things as assets or capitalized property (Muniesa et al. 2017, Birch 2020). Just as the transformation of a thing into a commodity has been, and remains, absolutely central to capitalist dynamics, "the transformation of [a] "thing" into an asset [has become] a way to organize, govern, and manage value and valuation over time' (Birch 2020, p. 11).

It is not one or the other way: capitalism seems to thrive on both accumulation strategies, fuelled by fictional expectations intersecting macro phenomena and locally embedded political-economic actions. By following the social life of soybeans, I have shown that the commodification of a thing could be interrupted by a process of assetization. Yet, my point is not merely about further theorizing the social life of things by establishing that there may be a variety of possible ontological becomings for things. It is also to stress that not only do commodities and assets (and related accumulation strategies) nestle beside each other, but they also incorporate each other's characteristics, change into each other, or confuse different actors about their commodity-versus-asset identities. Complex temporal processes of commodification and assetization can significantly mark the social life of the same 'thing.' The commodity phase in the social life of a thing can be interrupted, temporarily and precariously, by an asset phase.

These findings spark important questions for further research, including the possibility that any 'thing' turned into a commodity may be a potential candidate for assetization, and the various ways and moments in which technological innovations open up possibilities of temporarily neglecting the biophysical, therefore perishable, features of a commodity. Once sheltered, as biophysical assets, the materiality of soybeans still deeply matters as its conservation is the guarantee of its future value. This everyday problem can be fixed by technological means but the return to commodity life is always around the corner, as many natural and human threats remain challenging: defective closing of the bags at the moment of the filling, rupture of the bag by stones, the ingress of water or rodents into the bag, or even political incitements to 'cut the silobolsa for homeland.' Kean Birch has convincingly argued that 'existing STS literature has conceptualized value as an intrinsic (even latent) aspect of biological materiality' (Birch 2017a, p. 462), thereby neglecting processes of assetization and capitalization in value and valuation (Birch 2017a, p. 463, 2017b, 2020). My findings point to the fact that biological materiality appears surprisingly central to the theoretical and empirical examination of social practices and processes of valuation as commodification and assetization.

\section{Notes}

1. In spite of the success of this model in economic terms, there are numerous socio-technical controversies on social and environmental impacts attributed to the "soyization of Argentina" that fall out of the scope of the present paper (see Delvenne et al. 2013 and Arancibia 2013 for an overview), such as deforestation, the displacement of indigenous populations, tensions with other productive activities like cattle raising, soil degradation because of proliferating monocultures, and a rise of cancers and malformations due the increasing use of agrochemicals.

2. Extending Cochoy's (2007) analysis, Hawkins (2012) took the PET drink bottles example to analyze what happens to the package after the product it contains is consumed. While this problem of waste and environmental pollution related to packages is certainly an important one, it is beyond the scope of the present analysis of the politics of silobolsa.

3. More details about this context, and a more extensive version of these arguments, can be found in Delvenne (2017).

4. This commodity system is based on global tradability and its roots go back a long way, at least to the last thirty years of the 19th century: from 1870, economic growth was remarkable, and technical improvements made possible a more flexible and cheaper transportation. At the end of the 19th century, England, which was the 
heartland of the industrial revolution, turned to Argentina to be provided with the raw materials for its manufacturing (Barsky and Djenderedjian 2003). Hence the myth of the 'granary of the world' that persisted for some time and regularly resurfaces.

5. Actors use the terms 'technological package' to refer to the combination of glyphosate-based herbicides, no-till farming, and herbicide-tolerant soybeans to stress their joint and mutually reinforcing diffusion and commercialization. As this paper argues, silobolsa is equally central to, and interwoven with, these developments and, therefore, it should be included as an additional component to the technological package.

6. The Rosario Futures Exchange (Rofex), founded in 1909 and known locally as Mercado a Termino de Rosario, is an Argentina-based derivatives exchange offering futures and options contracts on several local agricultural commodities, energies, currencies, interest rate and stock index futures.

\section{Acknowledgements}

The author wants to express his gratitude to the three anonymous reviewers and the editors for their insightful and constructive comments on a first version of this article. Preliminary versions of the paper also greatly benefited from the careful readings and constructive comments from colleagues from the Spiral Research Centre (Liège, Belgium) as well as from the TIK Centre for Technology, Innovation and Culture (Oslo, Norway). Lastly, the author is indebted to Miguel Fusco and Carlos Roig for an eye-opening conversation on the neglected centrality of silobolsa in existing analyses of Argentine soybean agriculture.

\section{Disclosure statement}

No potential conflict of interest was reported by the author(s).

\section{Funding}

This article was supported by Fonds De La Recherche Scientifique - FNRS.

\section{Notes on contributor}

Pierre Delvenne holds a $\mathrm{PhD}$ in Political and Social Sciences of the University of Liège. He is currently Research Associate of the Fund for Scientific Research (FNRS), Lecturer at the University of Liège (Department of Political Science), and Associate Director of SPIRAL Research Centre. Pierre has published extensively in his areas of expertise: Technology Assessment, bioeconomy in Europe and Latin America, more broadly, science and technology in society. Previously he was a visiting Research Fellow in King's College University (United Kingdom), Harvard University (USA), Universidade Federal de Santa Catarina (Brazil), Universidad de Quilmes (Argentina) and University of Westminster (United Kingdom). Pierre is also a founding member of the Belgian Network for Science and Technology in Society Studies (BSTS).

\section{References}

Anlló, G., Bisang, R., and Campi, M, 2013. Claves para repensar el agro argentino. Buenos Aires: Editorial Universitaria. Arancibia, F, 2013. Challenging the bioeconomy: The dynamics of collective action in Argentina. Technology in Society, $35,79-92$.

Appadurai, A, 1986. The social life of things: Commodities in cultural perspective. Cambridge: Cambridge University Press.

Barsky, O., and Djenderedjian, J., 2003. Historia del capitalismo agrario pampeano. La Expansión ganadera hasta 1895. Buenos Aires: Siglo XXI.

Beckert, J, 2013. Capitalism as a system of expectations: Toward a sociological microfoundation of political economy. Politics \& Society, 41 (3), 323-350.

Birch, K., and Tyfield, D, 2013. Theorizing the bioeconomy: Biovalue, biocapital, bioeconomics or ... what? Science, Technology, \& Human Values, 38 (3), 299-327.

Birch, K, 2017a. Rethinking value in the bio-economy: Finance, assetization, and the management of value. Science, Technology, \& Human Values, 42 (3), 460-490.

Birch, K., 2017b. Financing technoscience: Finance, assetization and rentiership. In: D. Tyfield, R. Lave, S. Randalls, and C. Thorpe, (Eds.). The Routledge Handbook of the political economy of science. London: Routledge, $169-181$.

Birch, K, 2020. Technoscience rent: Toward a theory of rentiership for technoscientific capitalism. Science, Technology, \& Human Values, 45 (1), 3-33. 
Buzzato, P., et al., 2011. Logistics and economics of grain harvest and transport systems with the use of silo bag. ASABE Paper N. ${ }^{\circ} 1100019$. In ASABE annual international meeting, 7-10 de Agosto. Luiville, Kentucky, Unites States.

Cáceres, D, 2015. Accumulation by dispossession and socio-environmental conflicts caused by the expansion of agribusiness in Argentina. Journal of Agrarian Change, 15 (1), 116-147.

Callon, M, 1998. Introduction: The embeddedness of economic markets in economics. The Sociological Review, 46 (1), $1-57$.

Callon, M., Millo, Y., and Muniesa, F, 2007. Market devices. Oxford: Blackwell.

Carranza, M, 2005. Poster child or victim of imperialist globalization? Explaining Argentina's December 2001 political crisis and economic collapse. Latin American Perspectives, 32 (6), 65-89.

Clarín Economía, 2017. Los productores prefieren no vender. En el campo hay US\$10.000 millones en silo bolsas llenos de soja y maíz. Clarín Economía. Available at: https://www.clarin.com/economia/campo-us-10-000-millonessilo-bolsas-llenos-soja-maiz_0_HkRG1KiuZ.html [Accessed 30 July 2019].

Clarín Rural, 2019. La campaña agrícola. La cosecha de soja ... ¿todo al silo bolsa? Clarín Rural. Available at: https:// www.clarin.com/rural/cosecha-soja-silo-bolsa_0__wkoDzd65.html [Accessed 30 July 2019].

Cochoy, F, 2007. A sociology of market-things: on tending the garden of choices in mass retailing. The Sociological Review, 55 (2), 109-129.

Cronon, W., 1991. Nature's metropolis: Chicago and the Great West. New York: WW Norton \& Company.

D'Avella, N, 2014. Ecologies of investment: Crisis histories and brick futures in Argentina. Cultural Anthropology, 29 (1), 173-199.

Delvenne, P., Vasen, F., and Vara, A. M, 2013. The "soy-ization" of Argentina: The dynamics of the "globalized" privatization regime in a peripheral context. Technology in Society, 35 (2), 153-162.

Delvenne, P., 2017. Embedded Promissory Futures: The rise of Networked agribusiness in Argentina's Bioeconomy. In: V. Pavonem and J. Goven, (Eds.). Bioeconomies. Basingstoke: Palgrave Macmillan, 227-249.

Fraga, A., and Baistrocchi, G, 2011. Campo de batalla: crónicas de la resolución 125. Buenos Aires: Ediciones B Argentina.

Goulet, F, 2013. Narratives of experience and production of knowledge within farmers' groups. Journal of Rural Studies, 32, 439-447.

Goulet, F., and Hernández, V, 2011. Vers un modèle de développement et d'identités professionnelles agricoles globalisés? Revue Tiers Monde, 3, 115-132.

Hawkins, G, 2012. The performativity of food packaging: Market devices, waste crisis and recycling. The Sociological Review, 60 (2), 66-83.

Hawkins, G, 2018. The skin of commerce: Governing through plastic food packaging. Journal of Cultural Economy, 11 (5), 386-403.

Hernández, V, 2013. Genealogía de una elite rural: elucidación antropológica de una práctica de poder. Mundo Agrario, 13, 26.

Hora, R, 2010. La crisis del campo del otoño de 2008. Desarrollo Económico, 50 (197), 81-111.

Infobae, 2018. Los silobolsas son una oportunidad de exportación para la industria nacional. Infobae. Available at: https://www.infobae.com/campo/2018/10/06/los-silobolsas-son-una-oportunidad-de-exportacion-para-la-industri a-nacional/ [Accessed 30 July 2019].

Iprofessional, 2019. Vuelve el 'fantasma del silobolsa' justo cuando el Gobierno juega su suerte a los dólares de la soja. Iprofessional. Available at: https:/www.iprofesional.com/comex/288493-campo-divisas-Dolar-soja-y-eleccionessilobolsas-empanaran-el-plan-oficial [Accessed 30 July 2019].

International Accounting Standards Board (IASB), 2015. Information for observers: Accounting standards for small and medium-sized entities. London: IASB.

Jasanoff, S, 2004. States of knowledge: the co-production of science and the social order. London: Routledge.

Joly, P.-B, 2015. Governing emerging technologies? The need to think outside the (black) box. In: S. Hilgartner, C. Miller, and R. Hagendijk, (Eds.). Science and Democracy. Making Knowledge and making power in the Biosciences and beyond. New York: Routledge, 133-155.

Kulfas, M, 2016. Los tres kirchnerismos. Una historia de la economia Argentina 2003-2015. Buenos Aires: Siglo Veintiuno.

La Capital, 2018. Silo bolsa: el acopio que suma adeptos. La Capital. Available at: https://www.lacapital.com.ar/ agroclave/silo-bolsa-el-acopio-que-suma-adeptos-n1687841.html [Accessed 30 July 2019].

La Nación, 2015. Silobolsas: la revolución del agro que obsesiona al Gobierno. La Nación. Available at: https://www. lanacion.com.ar/economia/silobolsas-la-revolucion-del-agro-que-obsesiona-al-gobierno-nid1804417 [Accessed 30 July 2019].

La Voz, 2019. La venta de silos bolsa en Córdoba movería U\$S 36 millones. La Voz. Available at: https://www.lavoz. com.ar/negocios/venta-de-silos-bolsa-en-cordoba-moveria-us-36-millones [Accessed 30 July 2019].

Leguizamón, A, 2014. Modifying Argentina: GM soy and socio-environmental change. Geoforum, 53, 149-160.

Leguizamón, A, 2016. Disappearing nature? Agribusiness, biotechnology and distance in Argentine soybean production. The Journal of Peasant Studies, 43 (2), 313-330.

Mirowski, P, 1991. Postmodernism and the social theory of value. Journal of Post Keynesian Economics, 13 (4), 565-582. 
Muniesa, F, et al., 2017. Capitalization: A cultural guide. Paris: Presses des Mines.

Murcott, A, 2019. Introducing the sociology of food and eating. London: Bloomsbury Publishing.

Neyland, D., Ehrenstein, V., and Milyaeva, S, 2018. Mundane market matters: From ordinary to profound and back again. Journal of Cultural Economy, 11 (5), 377-385.

Otero, G, 2012. The neoliberal food regime in Latin America: State, agribusiness transnational corporations and biotechnology. Canadian Journal of Development Studies/Revue Canadienne D'études du Développement, 33 (3), $282-294$.

Penna, J., and Lema, D., 2003. Adoption of herbicide tolerant soybeans in Argentina: an economic analysis. In: N. Kalaitzandonakes, (Ed.). The economic and Environmental Impacts of Agbiotech. A global perspective. New York: Kluwer Academic, 203-221.

Perfil, 2019. Agricultores apuestan y proponen tasación de soja en Argentina. Perfil. Available at: https://www.perfil. $\mathrm{com} /$ noticias/bloomberg/bc-agricultores-apuestan-y-posponen-tasacion-de-soja-en-argentina.phtml [Accessed 30 July 2019].

Richardson, N, 2009. Export-oriented populism: Commodities and coalitions in Argentina. Studies in Comparative International Development, 44 (3), 228-255.

Teubal, M., and Teubal, H, 2011. La crisis de 2001-2002 y el colapso del neoliberalismo en la Argentina. Realidad Económica, 261, 58-84.

Trigo, E, et al., 2009. The case of zero-tillage technology in Argentina. Washington: International Food Policy Research Institute.

Tsing, A, 2013. Sorting out commodities: How capitalist value is made through gifts. HAU: Journal of Ethnographic Theory, 3 (1), 21-43.

Tsing, A, 2015. The mushroom at the end of the world: On the possibility of life in capitalist ruins. Princeton: Princeton University Press.

Winner, L, 1980. Do artifacts have politics? Daedalus, 109 (1), 121-136. 